\title{
Ex-post Assessment of the Global European Strategy
}

\section{Lenka Fojtíková ${ }^{1}$}

\begin{abstract}
The changing situation in the world economy is connected with growing competition on global markets. This new situation creates growing possibilities for some, for others loss of gains. The goal of the European Union is to be more competitive on the world market and to keep the leading position in world trade. The article focuses on an assessment of the EU trade strategy "Global Europe: Competing in the world", that was carried out in the period $2006-2010$. The analysis is provided in three steps. First of all, changes in the world economy as a factor influencing trade policy are shown. Secondly, the main priority areas of trade strategy are described. Finally, the progress achieved in the Global Europe strategy is analysed. Conclusions are based on method of deduction and calculation of changes in the EU's market share, trade integration and trade balance in 2006 - 2010. The results of trade analysis showed that preferential trade agreement is not a sufficient instrument for increasing trade and that more trade opportunities do not always have to mean lower unemployment.
\end{abstract}

Key words: trade policy, Common Commercial Policy, trade strategy, the WTO, mostfavoured nation, free trade agreement, market share, trade integration, trade balance

JEL Classification: F13, F15

\section{Introduction}

The European Union (EU) is an important economical, political and cultural centre of the world economy. It constitutes more than seven percent of the world's population and has the largest economy in the world (Euroskop, 2011). The EU is also the leading exporter, provider and recipient of foreign direct investments. However, statistical data prove that the EU share on world exports and imports is gradually declining.

Changes in the global economic order and the growing number of exporters that have been competitive on the world market during the last two decades caused redistribution of market shares between emerging and developed countries, and among developed countries themselves. The EU had to respond to this new situation in order to vindicate its leading role in world trade. The former EU Trade Commissioner Peter Mandelson ${ }^{2}$ (2007) argued that: "the EU has passed from its continental phase to its global phase." The central goal of the European Union in the last decade was to become the most competitive and the most dynamic knowledge-based economy in the world by 2010 .

\footnotetext{
${ }^{1}$ Doc. Ing. Lenka Fojtíková, Ph. D., Department of European Integration, Faculty of Economics, VŠB-Technical university in Ostrava, Sokolská 33, 70121 Ostrava 1; e-mail: lenka.fojtikova@vsb.cz

${ }^{2}$ Peter Mandelson, EU Trade Commissioner in 2004 - 2008.
} 
This goal was embodied institutionally in the Lisbon strategy in 2000 that was revised in 2005. Steps were set out in the renewed Lisbon strategy that the EU must deliver growth and jobs. It underlined that "an open market with high quality internal rules, effectively enforced, in areas such as competition, innovation, education, research and development, employment, social cohesion policy is essential in helping European companies compete globally" (European Commission, 2006a). It highlighted the need to ensure open markets around the world. Strengthening the European internal market and improving the EU's competitiveness in the global economy invoked the request to consider the EU trade policy as an integral part of a wider approach to economic reform and competitiveness. In 2006, Peter Mandelson presented the Commission with a new trade strategy "Global Europe - Competing in the World". This strategy integrated trade policy into the EU's competitiveness and economic reform agenda.

The paper focuses on the EU trade policy, especially the main priority areas of the trade strategy for 2006 - 2010 and the development of the EU's merchandise trade during this time. Using the method of deduction and trade analysis, it will show progress achieved in the Global Europe strategy. The analysis will be undertaken in three steps. In the first step, external challenges the EU is facing today are shown. In the second step shall present priority areas of trade strategy. And finally, progress in the Global Europe strategy will be discussed in the third step. The main intention will be to focus on changes in the EU's market share, trade balance and the level of the EU's trade integration in comparison with the unemployment rate in the period $2006-2010$. From this point of view, ex-post assessment of the Global Europe strategy should open the door for the consideration of the priority areas of the new EU trade strategy for the period $2011-2020$.

\section{Theoretical background of the EU trade policy}

Trade policy generally represents a complete framework of laws, regulations, international agreements and negotiating stances adopted by governments to achieve legally binding market access for domestic firms (Goode, 2003, pp. 356). Kerr (2007, pp. 1) states that trade policy deals with economic effects of direct or indirect government interventions that alter the environment under which international transactions take place. In the EU, trade policy is officially called the Common Commercial Policy (CCP) and represents one of the first areas in which the European Commission (EC) was granted exclusive competence ${ }^{3}$. The definition, scope and objectives of the CCP were set out in Articles 110-16 by the Treaty of Rome for the first time. The objectives were defined as follows: "to contribute, in the common interest, to the harmonious development of world trade, the progressive abolition of restrictions on international trade and the lowering of customs barriers" (Elsig, 2002, pp. 26). The $\mathrm{CCP}$ is based on uniform principles, particularly in regard to changes in tariff rates, conclusion of tariff and trade agreements, achievement of uniformity in measures of liberalisation, export policy and measures to protect trade such as those to be taken in case of dumping or subsidies (Elsig, 2002). The main institutional role in the realisation

\footnotetext{
${ }^{3}$ Exclusive competences means that the EU alone is able to legislate and adopt binding acts in fields such as customs union, competition rules within the internal market, common commercial policy, etc. The role of Member states' is therefore limited to applying acts, unless the Union authorises them to adopt certain acts themselves. See Article 3 of the TFEU.
} 
of the CCP is ascribed to the European Commission, the Council of the EU and the European Parliament. Since $1^{\text {st }}$ January 1970, the decisions under the CCP have been made by the qualified majority ${ }^{4}$.

The devolution of national competencies in the trade area to the supranational level is officially presented as an advantage in negotiations with third countries. To speak with one voice on behalf all the EU member states presents a strong negotiation position of the Commission. But practically it is often very difficult to reach a compromise among 27 countries $^{5}$. Some authors even consider the exclusive reliance on the Commission's negotiating abilities not efficient. It generates much frustration among EU's major trading partners, including China, which do not know who to talk to (Messerlin and Wang, 2008).

While the objectives of the CCP remain unchanged to this day, the scope of the CCP was gradually extended. It was influenced by the changing situation in international trade. After the Treaty of Rome had been signed, the Community's economy and external trade were geared mainly to production and trade in industrial products. Later, the services sector became the main source of jobs within the EU and accounts for a substantial proportion of its international trade. This change partly occured due to very stiff competition from newly industrialized countries in traditional sectors, and partly due to the economic changes brought about by the new information and communication technologies (Europa, 2012).

The GATT $^{6}$ negotiations also evoked necessary changes in the scope and decision methods in the CCP. In the GATT and later the WTO negotiations, the Community's attempts to speak with one voice during negotiations were often hindered by single member countries ${ }^{7}$. The shared competence of the Community and the member states in areas that were not included in the exclusive competence of the EU caused that negotiations proceeded slowly and very often with difficulties. Where the competence was shared, national ratification procedures were applied. This led to the delay of trade agreements coming into force (Elsig, 2002). This situation decimated the negotiation position of the EU with third countries.

\footnotetext{
${ }^{4}$ The qualified majority (QM) is the number of votes required in the Council for a decision to be adopted. The majority is represented by 255 votes out of a total of 345 . Moreover, a member state may request verification that the QM represents at least $62 \%$ of the total population of the Union. When the Lisbon Treaty came into force, a new system known as "double majority" was introduced. It will enter into force on $1^{\text {st }}$ November 2014. See http://europa.eu/legislation_summaries/glossary/qualified_majority_en.htm

${ }^{5}$ For example in 2008, at negotiations between member states of the EU and the Commission, twenty countries refused the proposal of the WTO about trade liberalization, and later the Commission had to present their stance in multilateral fora in the WTO. According to Elsig (2002, pp. 36), the work committe is divided into two camps: a liberal North (Great Britain, Germany, the Netherlands, Denmark, Luxembourg, and Ireland in non-agricultural matters) and a protectionist South (France, Spain, Portugal, Belgium, Greece and Italy).

${ }^{6}$ The General Agreement on Tarriffs and Trade (GATT) was signed in 1947. It is a predecessor of the World Trade Organization (WTO) that began work on $1^{\text {st }}$ January 1995.

${ }^{7}$ For example the Uruguay Round nearly collapsed in 1990 in Brussels at the Ministerial level due to the inflexibility of the European position in agriculture (Elsig, 2002).
} 
The first extension of the scope of the CCP was brought by the Maastricht Treaty in Article 133 (ex Article 113). It allows the Council, after consulting the Parliament, to lead international negotiations and to sign agreements on services and intellectual property rights where they are not already covered by the CCP. The Amsterdam Treaty as well as the Treaty of Nice was intended to further clarify the situation by providing the EU with an extended scope of the CCP. The second extension of the scope of the CCP was brought by the Lisbon Treaty ${ }^{8}$ that came into force on the $1^{\text {st }}$ December 2009 after having been ratified in national parliaments of the EU's member countries. According to article 207 (ex Article 133 TEC) of the Consolidated version of the Lisbon Treaty, the uniform principles of the CCP will be applied on trade agreements relating to trade in goods and services, the commercial aspects of intellectual property and foreign direct investment. The Lisbon Treaty extends the scope of exclusive competences in the $\mathrm{CCP}$, and thereby significantly reduces the need for further mixed agreements (Bungenberg, 2010).

A qualified majority is the main decision method of the Council in the realisation of the CCP now. But for the negotiation and conclusion of agreements in the fields of trade in services and the commercial aspects of intellectual property, as well as foreign direct investment, the Council shall act unanimously where such agreements include provisions for which unanimity is required for the adoption of internal rules ${ }^{9}$ (Treaty on the Functioning of the EU, article 207).

While the role of the European Parliament was only marginal, after the Lisbon treaty had come into force, the influence of the European Parliament was strengthened. It has the right to be consulted before a trade agreement and parliamentary consent is required in almost all cases of new agreements. It means that the European Parliament has the power to force the Commission and Council to respect environmental and human rights obligations in the area of the CCP. Trade policy can therefore be used in order to attain non-economic objectives (Bungenberg, 2010). This "politisation" of the CCP is often the subject of discussion ${ }^{10}$. In essence, it is possible to agree with Arcas (2008) that trade is about money, and money is a powerful instrument for fostering political relations.

\footnotetext{
${ }^{8}$ The Lisbon Treaty includes two treaties - the Treaty on the European Union and the Treaty on the Functioning of the European Union.

${ }^{9}$ The Council shall also act unanimously for the negotiation and conclusion of agreements in the field of trade in cultural and audiovisual services and in the field of trade in social, education and health services. See the Consolidated Version of the Functioning of the European Union.

${ }^{10}$ For example Štěrbová (2010) asks a question if the strengthening role of the European Parliament does not slow down and prolong reactions to the anti-competitive practices of foreign subjects, and if it shall not have a negative impact on the EU industry because of this. Another example of the politisation of the CCP is apparent from the paper „Closer Partners, growing responsibilities", where the Commission mentions the need to leverage the potential of a dynamic relationship with China based on the EU values, and tackles political issues such as human rights or China's transition towards a more open and plural society. Messerlin and Wang (2008) point out that such goals should be handled by the Europeans at large (governments and civil society), not by their trade negotiators.
} 


\section{Long-term trends in world economy as a factor influencing the EU trade policy}

Changes in the global economic order, such as the end of the Cold War and building of new democratic states, are significant for the world economy and international relations. Driven by growing trade, falling transportation costs, and revolution in information and communication technology, global economic integration is quickening. On the one hand, it creates opportunities for growth and for development, on the other hand it puts new pressures on global resources and create new competition for EU workers and industries. The world economy is therefore facing a new phenomenon. Emerging big open economies, such as BRIC ${ }^{11}$, play an increasingly important role in the world economy although the average standard of living there remains consistently lower than in the old industrialised countries (see Figure 1). While developed countries - the gross domestic product (GDP) in purchasing power parity (PPP) per head in the USA, the EU and Japan was higher than the world average, the developing BRIC was under the world average in 2008 all the time.

Figure 1: GDP per head of selected countries in 1960 - 2008 (GDP PPP in 2005 prices, \% of world average)

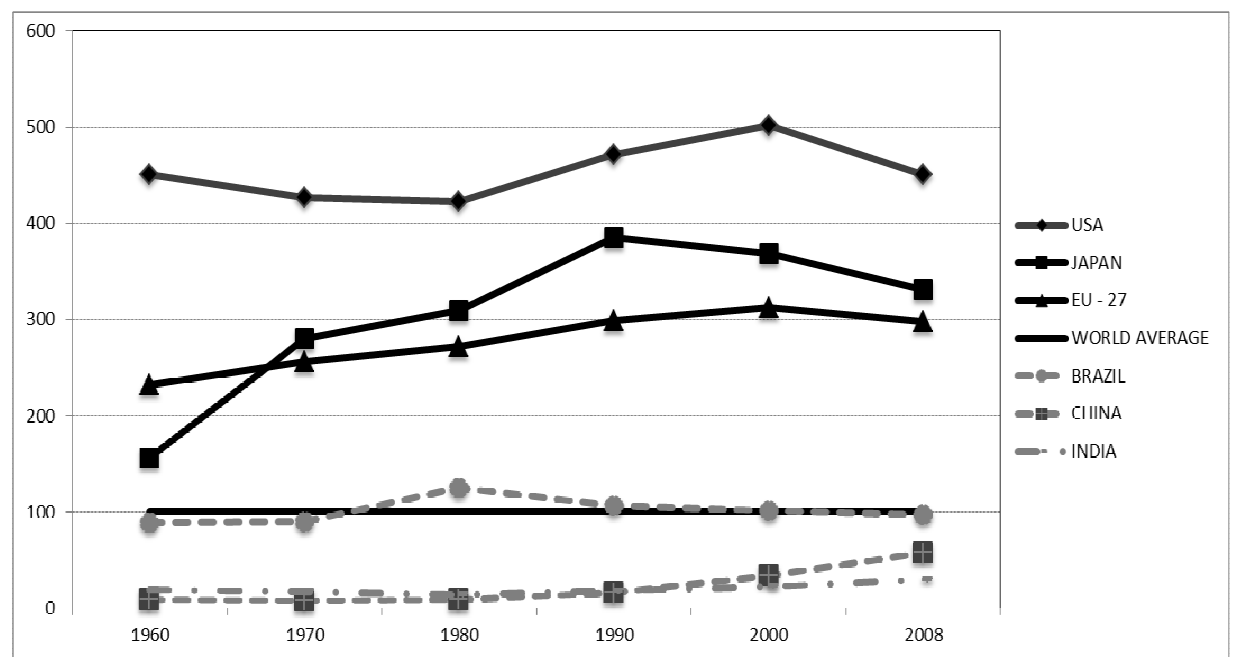

Source: Own figures based on data from CEP II, World Economic Overview, 2009.

In the long term tendency, it is evident that the EU and the USA recorded a decline of their share on the world production (see Figure 2). The decline of the EU's share on the world production was 9 p.p. in 1960 - 2008, much more than it was in the USA (-6.2 p.p.). Japan achieved fluctuating development, on the whole Japan increased its share on the world production by 1.4 p.p. at the same time. In contrast to the USA and the EU, the emerging BRIC recorded a growth of their share on the world production. Particularly China's progress marks an obvious contrast with the developments of the

${ }^{11}$ BRIC is a term used in economics to refer to the combination of Brazil, Russia, India and China. The term was first used in the thesis of Goldman Sachs investment bank. Goldman Sachs argue that the economic potential of Brazil, Russia, India and China is such that they may get among the four most dominant economies by 2050 (Arcas, 2008). 
EU and the USA, when its production share grew from $1.8 \%$ in 1960 to $11.3 \%$ in 2008 (CEP II, 2009). It was caused by the fact that some industries moved from developed countries to these low income countries, the aim here being to cut down production costs and achieve more production gains and competitiveness.

Figure 2: Share of selected countries on world production ( $\%$ of world total)

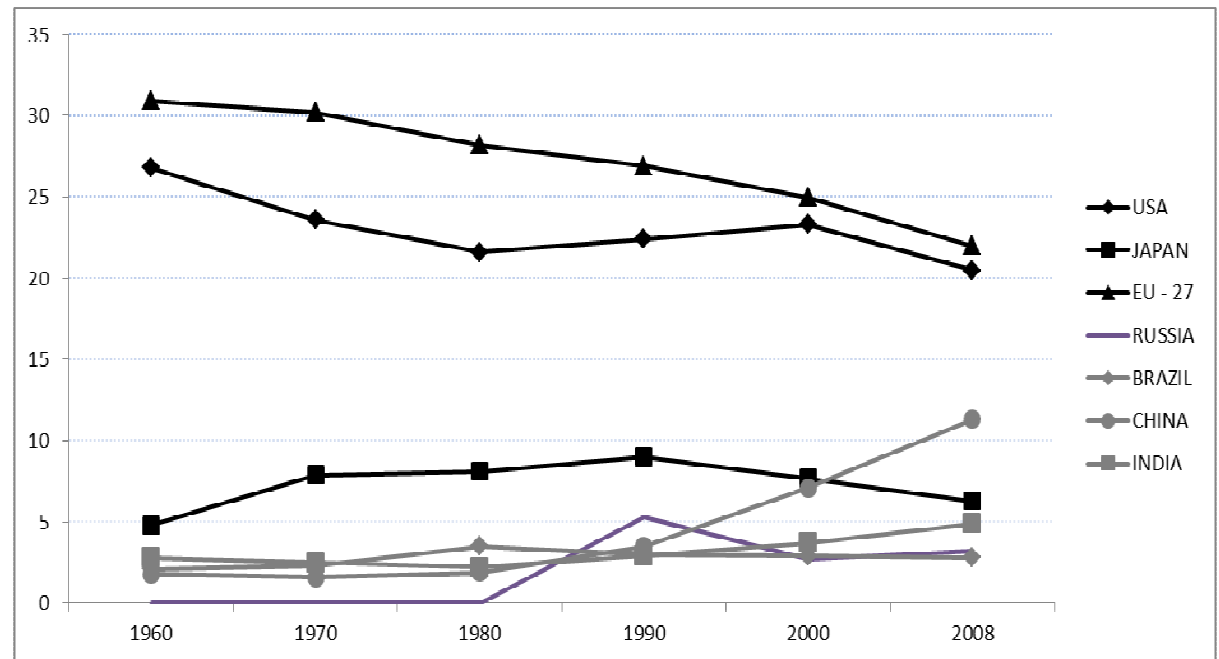

Source: Own figures based on data from CEP II, World Economic Overview, 2009.

Trends in the development share of selected countries on the world production are also reflected in their share on world exports. While the EU's share on world merchandise exports was $24.5 \%$ in 1960, it was only $16.0 \%$ in 2010 (Eurostat, 2011). It means that the EU recorded a decline of its share on world exports by $8.5 \mathrm{p}$. p. It was less that the USA recorded (-14.9 p.p.). It is surprising that the EU was more competitive when it included only six member countries (in 1960) than with 27 EU's countries ${ }^{12}$.

An opposite development was recorded during the last 50 years in China. Its share on world merchandise exports has grown by more than 12 p.p. Brazil, Russia and India too have increased their share on world exports in 1960 - 2010, but the growth was not enormous (only about 1 p.p.) ${ }^{13}$. You can see the long term development of the EU's share on world merchandise exports in comparison with the main EU's competitors in Figure 3.

The EU recorded a declining trend on the import side, too. While the EU's share on world imports was $23.5 \%$ in 1960 , it was only $17.3 \%$ in 2010 . The decline by 6.2 p.p. during the last fifty years on the import side was lower than was recorded on the export side. In comparison with the EU, the USA also recorded a decline of share on world imports, but only by 3 p.p. The import shares of BRIC were different. While China and

\footnotetext{
${ }^{12}$ Data in figures 3 and 4 reflect successive evolution of the EU from 6 to 27 member countries.

${ }^{13}$ For additional information see http://epp.eurostat.ec.europa.eu/cache/ITY_OFFPUB/KS-GI-11001/EN/KS-GI-11-001-EN-TOC.PDF
} 
India increased their share on world imports in 1960 - 2010 by 9 p.p., or by 2 p.p., respectively, Russia and Brazil achieved a small decline of their share (Eurostat, 2011).

Despite the successive EU's decline of share on world trade, the EU remains the world's most important source of goods. Analyses of the European Commission showed that the EU's companies are able to sell products at premium price because of quality, branding and related services. The Commission called these products ,up-market" products. Now they account for a third of the world demand and represent half of the EU exports, and it is not only luxury consumer goods, but a whole range of products, including intermediary goods, machinery and transport equipment (European Commission, 2008). The EU's comparative disadvantage in the primary sector is also balanced by a comparative advantage in the service sector and in high-tech products. With $18.5 \%$ of the world market for high-tech products in 2005, the EU has become the principal exporter ahead of the USA and Japan (Ibid, pp. 15). Although in this paper the EU is considered with 27 member countries, it is important to keep in mind that there are differences in member state performance, and there exist many routes to competitiveness.

Figure 3: Share of selected countries on world merchandise exports in 1960 - 2010 $(\%)$

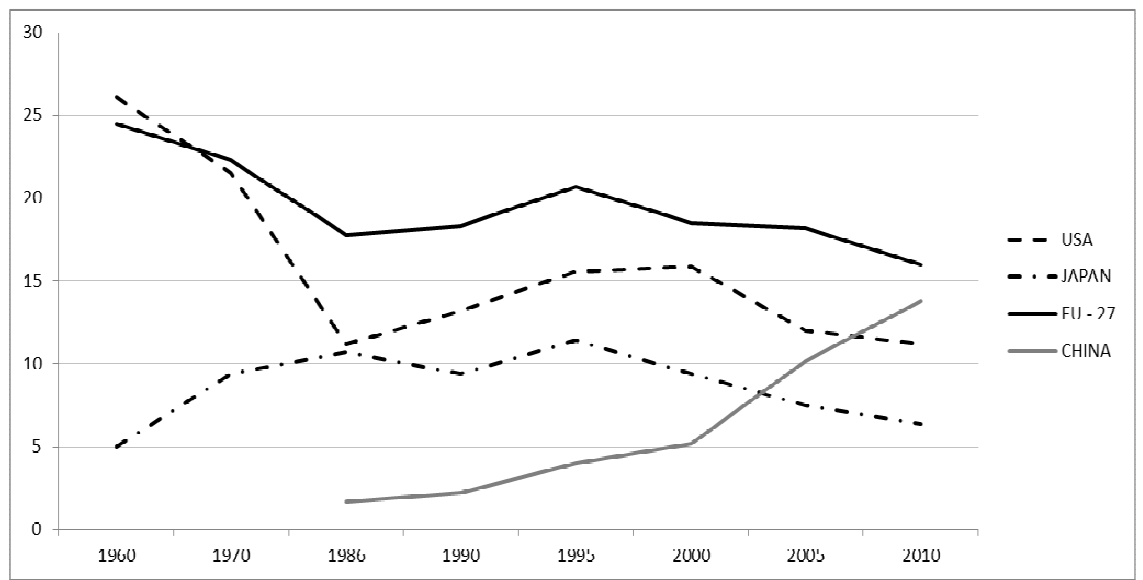

Source: Own figures based on data from Eurostat, 2011.

In 2005, the EU recorded the most important market share in Russia (54\%), Brazil $(30.5 \%)$ and India (28\%). The EU's market share in China was below its global market share (it was $19.5 \%$ in 2005). But the EU's export performance varies significantly between the destination markets over the period. Table 1 shows the fact that the $\mathrm{EU}^{14}$ has lost significant market share on some of the fast-growing emerging markets, particularly in Asia (11 percentage points loss in India, for instance). The loss on the Russian market was also significant (-9 p.p. loss). The EU's market share in China was also declining (almost 2 p.p.) in the period 1995 - 2005. In the long run, this

${ }^{14}$ Table 1 shows data for 25 EU member states. 
underperformance on some of the most promising markets could undermine the overall position of European Union in international trade ${ }^{15}$.

Table 1: Change in the EU's market shares on selected markets in 1995 - 2005

\begin{tabular}{|c|c|c|c|c|c|c|c|}
\hline \multicolumn{2}{|c|}{ China } & \multicolumn{2}{c|}{ India } & \multicolumn{2}{c|}{ Brazil } & \multicolumn{2}{c|}{ Russia } \\
\hline $\begin{array}{c}\text { Market } \\
\text { share- }\end{array}$ & $\begin{array}{c}\text { p.p. } \\
\text { change } \\
1995-\end{array}$ & $\begin{array}{c}\text { Market } \\
\text { share- } \\
2005\end{array}$ & $\begin{array}{c}\text { p.p. } \\
\text { change } \\
1995-\end{array}$ & $\begin{array}{c}\text { Market } \\
\text { share- } \\
2005\end{array}$ & $\begin{array}{c}\text { p.p. } \\
\text { change } \\
1995- \\
2005\end{array}$ & $\begin{array}{c}\text { Market } \\
\text { share- } \\
2005\end{array}$ & $\begin{array}{c}\text { p.p. } \\
\text { change } \\
1995- \\
2005\end{array}$ \\
\hline $14.0 \%$ & -1.82 & $28.0 \%$ & -11.12 & $30.5 \%$ & -1.17 & $54.0 \%$ & -9.13 \\
\hline
\end{tabular}

Source: Own table based on data from European Commission, 2008.

Likewise, historical data about development of the world population prove that China and India are the most populous countries (see Figure 4). From this point of view, this factor of population should also play an important role in the consideration of the EU trade support for the future.

Figure 4: Population of selected countries in $1960-2008$ (World = 100)

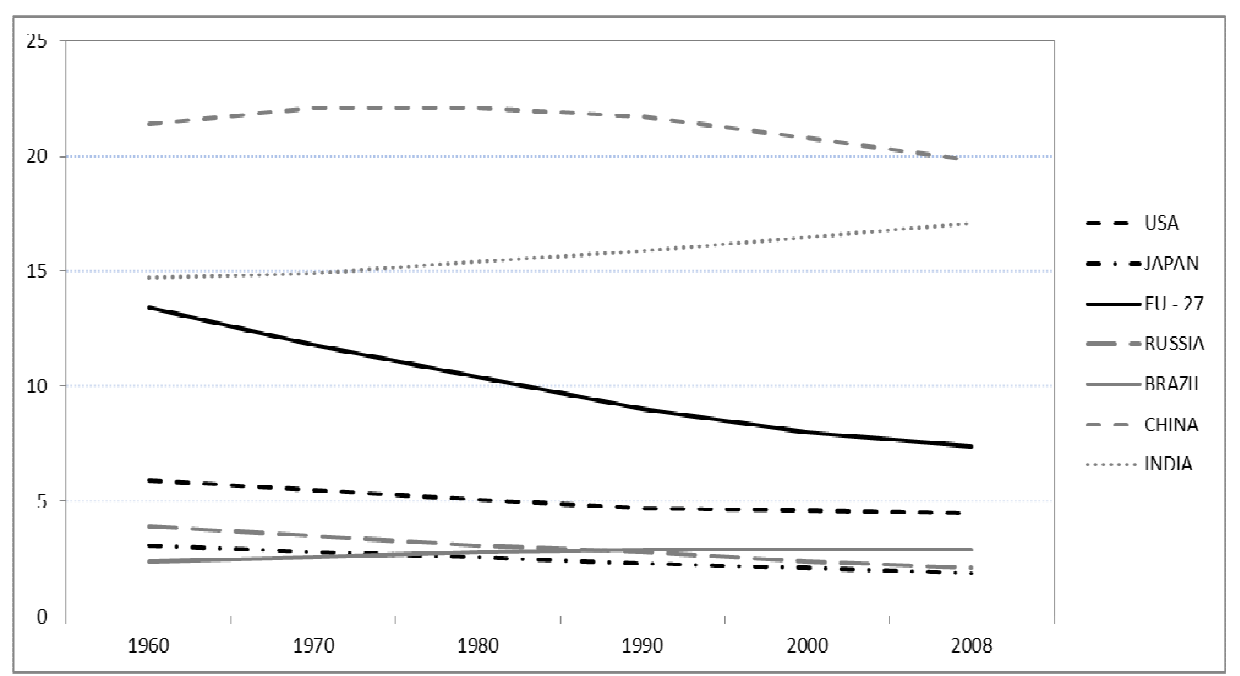

Source: Own figure based on data from CEP II, World Economic Overview, 2009.

\section{Specification of the EU trade strategy - "Global Europe"}

The changing global economy has become appealing for the EU. In order ,not to be a wall against globalisation but a way of engaging in it" (Mandelson, 2007), the European Commission adopted a new strategy to integrate trade policy into the EU's

${ }^{15}$ In contrast, the EU's market share in the USA remained stable over the period (1.5 p.p. increase) at one fifth of the import market in 2005 (European Commission, 2008). 
competitiveness and economic reform agenda. The policy review "Global Europe: Competing in the World" set out a strategy for opening new markets abroad for EU companies to trade in, ensuring that European companies would be able to compete fairly in those markets. The Global Europe strategy covered the period $2006-2010$ and proposed eight specific areas of action (European Commission, 2010a):

- The WTO Doha Development Agenda.

- Launch of new competitiveness-driven free trade agreements.

- Transatlantic trade and competitiveness.

- China.

- Intellectual property rights enforcement.

- Renewed Market Access Strategy.

- Public Procurement.

- Review of the Trade Defence Instruments.

Two thirds of the EU extra-EU imports are incorporated as inputs in the production process (European Commission, 2008). This very high share of inputs in the total EU imports, even when energy products are excluded, demonstrates very clearly that the EU as a whole relies heavily on global sources for inputs incorporated in its production process. To ensure higher competitiveness on the world markets, the EU rejects protectionism at home (on the EU internal market) and supports opening markets abroad. The EU promotes free trade upon multilateral, as well as bilateral negotiations.

Support of multilateral trade liberalisation that is carried out in the WTO is the first priority the EU. Despite the continued growth of EU's extensive network of preferential trade agreements, some $85 \%$ of the total EU imports entered under the $\mathrm{MFN}^{16}$ regime in 2008, highlighting the fundamental importance of the multilateral trading system for EU trade (WTO, 2011a). At this time, this "non-preferential trade" was realised by the EU with only nine countries, such as the USA, Australia, Canada, Japan, New Zealand, Hong Kong/China, Taiwan, South Korea and Singapore. Through the WTO, the EU seeks to ensure new markets for European companies, observe the rules and make sure others also play by the rules and promote sustainable development in trade.

In the Global Europe strategy, the EU identified the successful conclusion of the Doha Development Agenda (DDA) as the EU's top priority. The main attention of the EU has been focused on the areas of non-agricultural market access (removing tariff peaks and tariff escalation), liberalisation of trade in commercial services, public procurement and enforcement of intellectual property rights.

The Doha Development round was launched in 2001 and the original intention of the WTO members was to conclude negotiations at the sixth Ministerial Conference in Hong Kong in 2005. The work programme included a large spectrum of areas. The subject of negotiations was agriculture, services, market access for non-agricultural products, trade related aspects of intellectual property rights and other so called

\footnotetext{
${ }^{16}$ The most-favoured-nation (MFN) treatment is the principle of not discriminating between one's trading partners (see GATT Article I, GATS Article II and TRIPS Article 4). In other words, the MFN principle is about treating other WTO members equally.
} 
"Singapore issues"17. However, until now, trade ministers have been unable to reach any final agreement on all details to be concluded in the negotiating package. The main single issue that prevented the WTO members from reaching an agreement on the Doha Round modalities ${ }^{18}$ in July 2008 was the special safeguard mechanism that developing countries could use in the event of a significant surge in imports of agricultural products $^{19}$. From the second half of 2008 onwards, the main obstacles have been tied to external factors, such as uncertainty over the consequences of the economic crisis on various sectors in the WTO member economies, which prompted policy-makers to take a more defensive stance. Elections and changing governments in some key WTO member states also led to re-positioning in the negotiations (European Commission, 2010a). Although the EU accepted the demands of WTO member countries and took compromise suggestions ${ }^{20}$, it presented the stance of only 27 EU member states from the overall number of 153 members of the WTO. The consequences of the Single Undertaking, which expresses "all or nothing" taken by the WTO members at the start of the negotiations, impede the conclusion of the Doha Development Round.

The second specific areas of Global Europe are free trade agreements (FTAs). These fall into a number of categories. There are the Association Agreements with states in south eastern Europe (Western Balkan) and the Euro-Med partners that have been largely motivated by a desire to promote economic development and political stability in the EU's near neighbourhood (the political aspects included into the trade agreement have been mentioned before). There are the Economic Partnership Agreements with the Africa Caribbean and Pacific states that are largely motivated by development policy objectives. Finally, there have been the bilateral FTAs concluded with South Africa, Mexico and Chile and the region-to-region negotiation underway with Mercosur that is more commercially motivated. In addition to these full-fledged FTAs, there is a whole range of other co-operation agreements, including efforts to promote regulatory cooperation with the USA. The history of contracting FTAs is long and the attitude to their concluding has changed. ${ }^{21}$

\footnotetext{
17 „Singapore issues“ in the DDA include investment, competition, transparency in government procurement and trade facilitation. They are called "Singapore issues" because they were open to negotiation at the WTO Ministerial Conference in Singapore in 1996.

${ }^{18}$ Modalities refer essentially to the specific numerical targets, various flexibilities and other parameters that would define specific commitments the WTO members would need to undertake on industrial and agricultural products.

${ }^{19}$ There were a number of studies published to assess the economic impact of the Doha Round for the world. For example CEP II (2011) finds that agriculture would contribute $25 \%$ of the world income gains, industrial products would contribute $32 \%$ and services $43 \%$. The main winners from a substantial tariff reduction for industrial products were found either within advanced developing countries or small developer countries, in terms of relative gains expressed as a percentage of GDP. But the gains for the poorest would be limited.

${ }^{20}$ Suggestions included inter alia minimum average cuts of $54 \%$ and $38 \%$ to EU bound tariffs for agricultural and industrial products, respectively, and to reduce its overall trade distorting subsidies for agriculture by $80 \%$. The EU also forcefully argued for more liberalisation in services, and for substantial reductions in non-tariff barriers (European Commission, 2010).

${ }^{21}$ Although it was not a formal policy, the EU exercised a de facto moratorium on new FTA negotiations in 1999. It was a consensus of the member states and the Commission during the preparations for the Millennium Round of the WTO. Under the direction of the EU Trade
} 
The Global Europe strategy focuses on a new generation of FTAs. Until now, bilateral agreements have supported the EU's neighbourhood and development objectives, but the main trade interest was limited. In order for the trade policy to help create jobs and drive growth, economic factors must play a primary role in the choice of future FTAs. The Commission staff document states: "The decision to launch negotiations should be taken case-by-case, based on these economic criteria but also our partners' readiness and broader political considerations" (European Commission, 2006b). New FTAs should also include provisions for investment, IPR, public procurement and competition. The key economic criteria for new FTA partners should be market potential (economic size and growth) and the level of protection against the EU export interests (tariff and non-tariff barriers). Based on these criteria, ASEAN, Korea, Mercosur, India, Russia and the Gulf Cooperation Council emerged as priorities (Ibid). Other ongoing bilateral trade negotiations are not covered by the Global Europe approach, but they have an important role to play in achieving the objectives set out in Global Europe (European Commission, 2010a).

Transatlantic trade is another part of Global Europe. The transatlantic trading relationship between the EU and the USA is by far the largest in the world although it passes off on the principle of MFN, without any preferential treatment. The EU and the USA economies account together for about half of the entire world GDP and for nearly a third of world trade flows. Investments and trade are the real drivers of the transatlantic relationship, contributing to growth and jobs on both sides of the Atlantic. The value of their bilateral trade daily achieves EUR 1.7 billion (Europa, 2012). Despite this fact, there are a lot of non-tariff barriers that negatively affect trade between the EU and the USA. A study from 2009 estimated that the removal of half of the existing nontariff measures and regulatory divergences would translate into an increase in GDP of EUR 163 billion by 2018 on both sides of the Atlantic (EC-DG Trade, 2012). The main interest of Global Europe focused on removing non-tariff barriers and promoting enforcement of intellectual property rights against piracy and counterfeiting (European Commission, 2006b).

A new relationship with China presents another part of the Global Europe strategy. China's economic rise is affecting all areas of the world economy. And from this point of view, an economically strong China with a rapidly increasing middle class is a growing opportunity for EU exports. But until now, the EU has regularly been recording a bilateral deficit in trade with China. The main reason of this is seen in barriers to access the Chinese market, especially in the form of non-tariff barriers ${ }^{22}$. The lack of effective intellectual property protection is another threat for the EU producers. To better reflect the importance of their relations, the EU and China agreed on a strategic

Commissioner Pascal Lamy, the priority was a multilateral round. In 2003, the Commission issued a policy statement which presented the view that the DDA remained a priority, but the FTAs would not be ruled out in principle if they offered clear economic benefits and, in cases of region-to-region agreements, the EU's partners showed evidence of progress towards regional integration. During the Prodi Commission, the DG Trade Commission kept to the moratorium because new bilateral negotiations would have weakened the EU's position in pushing for a comprehensive multilateral round (Woolcock, 2007).

${ }^{22}$ Costs from non-tariff barriers in China were calculated at the value of EUR 20 billion. See http://ec.europa.eu/trade/. 
partnership in 2003 on the basis of the idea that "Europe and China can do more to promote their own interests together than they will ever achieve apart" (European Commission, 2006c). The key objective of the negotiations for a new Partnership and Cooperation Agreement (PCA), which will also update the 1985 Trade and Cooperation Agreement, will be better access to the Chinese market for European exporters and investors, going beyond WTO commitments, better protection of intellectual property and mutual recognition of geographical indications. Negotiations on a comprehensive PCA started in January 2007.

The area of intellectual property rights (IPR) was a hot topic before the admission of the Global Europe strategy ${ }^{23}$. In the knowledge-based economy, companies rely heavily on IPR to compete effectively in third country markets. Therefore, the protection of IPR has to be ensured by trade policy instruments. Since the adoption of Global Europe, the Commission has taken several initiatives in this field, such as monitoring the implementation of the IPR clauses included in the existing FTAs, reinforcing specific IPR dialogues with certain key partners such as China, Russia, Ukraine, etc., promoting the debate on IPR enforcement, often in cooperation with the USA, Japan and Switzerland in the WTO, expanding technical assistance initiatives to third countries with enforcement and providing support in particular to EU small and medium-sized enterprises operating in these countries, negotiating the Anti-Counterfeiting Trade Agreement to tackle the growing international trade of IPR-infringing goods, engaging in customs cooperation on IPR enforcement with the EU's main trading partners, etc. (European Commission, 2010a).

The market access strategy (MAS) helps European companies access third country markets by providing information on market access conditions and removing market access barriers. The MAS was launched in 1996, after the Uruguay Round, in order to help enforce multilateral and bilateral trade deals and open third countries markets. The Market Access Database was created to help implement this strategy ${ }^{24}$. The renewed MAS, as a part of the Global Europe strategy, was focused on identifying and prioritising sectors and markets where the removal of trade barriers would create the greatest gains for EU exporters. The renewed MAS started operating on the partnership structure involving the Commission, the EU member states and business. It led to a regular review, announcement of priorities and reporting on progress made ${ }^{25}$.

An initiative to open third countries public procurement ${ }^{26}$ markets was considered to be another possibility of how to increase the competitiveness of the EU's producers on the third markets. Now government procurement accounts for $16 \%$ of the EU GDP and can be as high as $20-30 \%$ in developing and emerging countries (European Commission,

\footnotetext{
${ }^{23}$ The Commission adopted the Strategy for the Enforcement of IPR in Third Countries in 2004.

${ }^{24}$ Free access into the database on www.madb.europa.eu.

25 The significance of MAS occurred especially during the world economic crisis in 2008-2009. Thanks to the existing MAS, the Commission was able to provide crucial information for the WTO and G20 initiatives to prevent protectionist tendencies following the financial crisis (European Commission, 2010).

${ }^{26}$ Public procurements are purchases of public authorities for public money. They are often considered as a key instrument of public policies, regional integration and an important component of development.
} 
2010a). Global Europe was supposed to eliminate discrimination practises of third countries, which prevented the EU producers from accessing their public markets. In 2006 - 2010, the Commission led bilateral negotiations in this case and also initiated extending the membership and the coverage of the Agreement on Government Procurement (GPA) ${ }^{27}$ in the WTO.

Global Europe also called for an update and modernisation of trade defence instruments (TDI $)^{28}$, started by the Green Paper at the end of 2006. But the reform of TDI had to be postponed because of the lack of consensus among the EU member states, especially in the time of the economic crisis. The main object of the reform was to make sure that TDI are used effectively, and to adapt their using to the changes in the global economy (European Commission, 2006c).

\section{Discussion on the progress of the Global Europe strategy}

The main object of the Global Europe strategy was to contribute to more competitiveness of the EU in the world. As Mandelson said,: "A stronger EU economy at home means Europe has to be more competitive abroad" (European Commission, 2006a). How the EU was successful in increasing its share on world merchandise trade ${ }^{29}$ in the period $2006-2010$ is shown in table 2.

Table 2: EU's share on world merchandise trade in 2006 - 2010, value of billion euro $(\%)$

\begin{tabular}{|l|c|c|c|c|c|c|}
\hline & 2006 & 2007 & 2008 & 2009 & 2010 & 2006-2010 p. p. \\
\hline Exports & 17.5 & 17.4 & 16.7 & 17.2 & 16.0 & -1.5 \\
\hline Imports & 19.0 & 19.1 & 19.1 & 18.0 & 17.3 & -1.7 \\
\hline
\end{tabular}

Source: Own table based on data from the European Commission (2011) and own calculation.

Based on the changes in market share, the long-term tendency in the decline of the EU's market share continued in the period 2006 - 2010. During the period under consideration, the EU share on world exports and imports declined by 1.5 p.p. and 1.7 p.p. It was influenced by several factors, mainly by the financial crisis, and the subsequent credit crunch and recession that caused the fall of foreign as well as domestic demand. According to the WTO report (2010), in 2009 the world GDP

\footnotetext{
${ }^{27}$ The Agreement on Government Procurement is a plurilateral treaty with 15 parties: Armenia, Canada, the EU, Hong Kong, Iceland, Israel, Japan, Korea, Liechtenstein, the Netherlands with respect to Aruba, Norway, Singapore, Switzerland, Chinese Taipei, the United States.

${ }^{28}$ TDI include anti-dumping, anti-subsidy, or safeguard measures carried out to defend the EU's producers against unfairly traded or subsidised imports and against dramatic shifts in trade flows in so far as these are harmful to the EU economy. For additional information about TDI see http://ec.europa.eu/trade/.

${ }^{29}$ The position of the EU in the world trade in commercial services was not analysed in this paper, because data that were published by Eurostat in 2007 and 2008 cover the period 2001 2005 , respectively $2003-2006$. Data that were published by the WTO are also not accessible in the demanded structure and for the considered period. Moreover, Global Europe did not devote special attention to the services sector.
} 
dropped by $2.3 \%$, world exports and imports fell by $12.2 \%$ and $12.9 \%$, respectively, in real impression. In nominal value, merchandise trade dropped by $23 \%$ and commercial services trade fell by $13 \%$ in 2009 . Although the decline of trade was synchronised across countries and regions, the EU decline of trade was higher than was the world average, $-14.8 \%$ on the export side and $-14.5 \%$ on the import side. The crisis also strengthened protectionism in different forms (growth of export as well as import tariffs, non-tariff barriers, government intervention and subsidies to particular sectors, preference of domestic producers, currency wars, etc.) in world trade, although at the world forum, represented by the summits of the $\mathrm{G} 20^{30}$, the meetings of the WTO, etc., protectionism was refused $^{31}$. Sectoral polarisation of EU exports was another factor that had a negative impact on the EU trade in the monitored. Huge losses were recorded in automotive products, industrial machinery, office and telecom equipment, iron and steel, etc. (WTO, 2010). In other words, the world exports declined especially in the products in which the EU had achieved a revealed comparative advantage. Fiscal imbalance and debt crisis in the Eurozone also had a negative influence on the European economy in the last years.

The global economic crisis could also be seen on the rate of openness of the EU economy that was lowest in 2009 (see Figure 5). In this period, people consumed less, hence produced less, and also exported and imported less. Although the share of import on the GDP was higher than the share of export on the GDP, the EU's trade integration grew on the export side more (by 1.1. p.p.) than it did on the import side (0.7. p.p.) in the period under consideration. Because the EU integrated with third countries more in import than export, the EU's trade balance was negative all the time (see Table 3). The EU recorded the highest trade deficit in the value of EUR 256.4 billion in 2008. The economic crisis reduced the trade deficit of the EU to EUR 109.4 billion in 2009, but after the revival of demand and economic activity, the trade deficit began to growth again.

\footnotetext{
${ }^{30} \mathrm{G} 20$ is a group of finance ministers and central bank governors from 20 major leading economies (19 countries + EU representatives).

${ }^{31}$ At the Washington Summit in November 2008, the G20 committed to a self-imposed standstill in terms of new barriers to investment or to trade in goods and services, new export restrictions or WTO inconsistent measures to stimulate exports. The London summit in April 2009 reinforced this commitment, notably by providing an explicit mandate to the WTO to monitor and to report publicly on the evolution of the situation on a quarterly basis. See http://europa.eu/rapid/pressReleasesAction.do?reference=IP/09/1681. In 2010, leaders reaffirmed the extension of their standstill commitment to resist protectionism until the end of 2013 and asked the WTO, OECD, and UNCTAD to continue monitoring the situation and to report publicly on a semi-annual basis. For additional information see http://www.oecd.org/dataoecd/56/48/43689944.pdf
} 
Figure 5: Trade integration of the EU (\% of GDP)

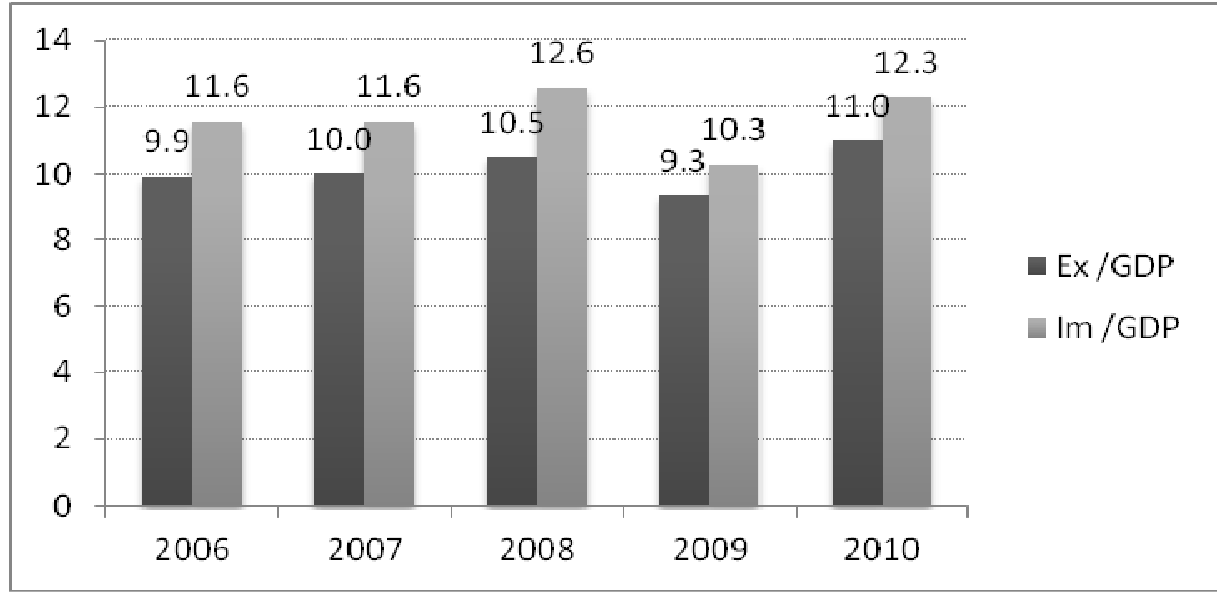

Source: Own processing based on data from Eurostat, 2012.

Table 3: Trade balance of the EU in 2006 - 2010 (mil. of EUR)

\begin{tabular}{|l|c|c|c|c|c|}
\hline & 2006 & 2007 & 2008 & 2009 & 2010 \\
\hline Export & 1160101 & 1240556 & 1309885 & 1097142 & 1347948 \\
\hline Import & 1352787 & 1435015 & 1566309 & 1206495 & 1506934 \\
\hline Trade balance & -192686 & -194459 & -256424 & -109353 & -158986 \\
\hline
\end{tabular}

Source: Own table based on data from Eurostat (2012) and own calculation.

The Global Europe strategy promoted open trade in a multilateral (in the WTO, the G20 summits) as well as bilateral way (FTAs). The idea was that more trade led to higher growth and new jobs in the EU. Table 4 compares the level of the EU's trade integration with the unemployment rate in the period of 2006 - 2010. Trade integration was calculated as:

\section{$\frac{E x+\operatorname{Im}}{G D P} \cdot 100$}

Table 4: The EU's trade integration and unemployment rate in $2006-2010$ (\%)

\begin{tabular}{|l|c|c|c|c|c|}
\hline & 2006 & 2007 & 2008 & 2009 & 2010 \\
\hline Trade integration rate & 21.5 & 21.6 & 23.1 & 19.6 & 23.3 \\
\hline Unemployment rate & 8.2 & 7.2 & 7.1 & 9.0 & 9.6 \\
\hline
\end{tabular}

Source: Own table based on own calculation and data from Eurostat (2012).

Table 4 shows that the rate of the EU's trade integration was higher in 2010 than in 2006, but the unemployment of the EU also grew. In other words, although the EU was a more open economy and tried to carry out a liberal trade policy according to the 
Global Europe strategy, the labour market was influenced not only by trade, but by other factors, too. An OECD study concluded that trade affects neither the overall employment, nor the unemployment rate. Other factors, such as technological change, are a more important cause of changes in employment patterns in industrialised countries (European Commission, 2010b).

The changes in the positions of the main trade partners of the EU in $2006-2010$ are shown in Table 5. The main trading partners of the EU were the USA, China, Russia and Switzerland. It should be mentioned that although the EU and the USA did not sign any preferential agreement that would grant them more a comfortable access to their markets, this bilateral trade is the most "flowering". While the four positions were not changed in the period under consideration, other positions were indeed. The fifth and the sixth positions of the EU's main partners were taken by Japan and Norway. Turkey occupied the eighth position the whole time. Other positions belonged to South Korea, India and Brazil. Canada took the tenth position among the EU's main trade partners in 2006, but it disappeared from the list of the ten main trade partners of the EU in the following years. In 2010, these ten countries participated in the total EU trade (export + import) by approximately by $62 \%$. On the whole, we can say that the structure of the EU main trade partners in 2006 - 2010 largely covered the priority countries indicated in the Global Europe strategy. It included the EU's bilateral negotiations with:

- the USA and the establishment of the Trans-Atlantic Economic Council in 2007,

- China and the establishment of the EU-China High Level Economic and Trade Dialogue,

- Russia, where the negotiations began in 2008 on a new bilateral agreement, but the EU-Russia bilateral trade relations have been rendered more problematic because Russia extended the protectionist measures in 2009 in order to protect the domestic producers in the time of the economic crisis,

- South Korea, where negotiations were launched in 2007 and also successfully concluded and ended by the most comprehensive EU-Korea FTA. The agreement has been provisionally applied since $1^{\text {st }}$ July 2011 ,

- India, where negotiations were launched in 2007 and nine rounds have been held since. However, an ambitious agreement with India has still not been concluded,

- Brazil as a part of Mercosur where FTA negotiations between the EU and Mercosur were launched in 1999, stalled in 2004 and re-launched in 2010,

- Canada, where negotiations on a Comprehensive Economic and Trade Agreement were launched in 2009.

Trade policy is a slow process that requires careful planning, it takes about five years to launch, complete and implement FTA negotiations, and more for multilateral negotiations (European Commission, 2010). From this point of view, it is complicated to measure the success of Global Europe according to the number of new FTAs. However, the positive thing is that the EU has achieved the indigenous intention of Global Europe, it is increasing the EU's trade share on the most dynamically growing markets. Table 5 shows that Brazil, Russia, India and China occurred among the ten leading trade partners of the EU in 2010. 
Table 5: The EU's leading trade partners in 2006 - 2010

\begin{tabular}{|c|c|c|c|c|c|c|c|c|c|c|c|}
\hline \multirow{3}{*}{2006} & Rank & 1. & 2. & 3. & 4. & 5. & 6. & 7. & 8. & 9. & 10. \\
\hline & Country & USA & China & Russia & Switzer. & Japan & Norway & Turkey & S.Korea & India & Canada \\
\hline & Bil.€ & 445 & 259 & 213 & 159 & 122 & 118 & 92 & 64 & 47 & 46 \\
\hline \multirow{3}{*}{2007} & Rank & 1. & 2. & 3. & 4. & 5. & 6. & 7. & 8. & 9. & 10. \\
\hline & Country & USA & China & Russia & Switzer. & Japan & Norway & Turkey & S.Korea & India & Brazil \\
\hline & Bil.€ & 433 & 304 & 234 & 169 & 122 & 120 & 100 & 66 & 56 & 64 \\
\hline \multirow{3}{*}{2008} & Rank & 1. & 2. & 3. & 4. & 5. & 6. & 7. & 8. & 9. & 10. \\
\hline & Country & USA & China & Russia & Switzer. & Norway & Japan & Turkey & S.Korea & Brazil & India \\
\hline & Bil.€ & 427 & 326 & 283 & 178 & 140 & 117 & 100 & 65 & 62 & 61 \\
\hline \multirow{3}{*}{2009} & Rank & 1. & 2. & 3. & 4. & 5. & 6. & 7. & 8. & 9. & 10. \\
\hline & Country & USA & China & Russia & Switzer. & Norway & Japan & Turkey & S.Korea & Brazil & India \\
\hline & Bil.€ & 355 & 296 & 183 & 162 & 106 & 93 & 80 & 54 & 53 & 47 \\
\hline \multirow{3}{*}{2010} & Rank & 1. & 2. & 3. & 4. & 5. & 6. & 7. & 8. & 9. & 10. \\
\hline & Country & USA & China & Russia & Switzer. & Norway & Japan & Turkey & India & S.Korea & Brazil \\
\hline & Bil.€ & 413 & 396 & 246 & 188 & 121 & 110 & 104 & 68 & 67 & 64 \\
\hline
\end{tabular}

Source: European Commission - DG Trade, 2012.

Although the USA has kept the leading position among the EU trade partners, its share on the total EU exports declined by 5.2 p.p. in the period $2006-2010$. Contrary to the USA and Japan, the share of BRIC on the EU exports grew in the same time (see Table $6)$.

Table 6: The share of selected countries on the EU exports in $2006-2010$ (\%)

\begin{tabular}{|l|c|c|c|c|c|c|}
\hline & 2006 & 2007 & 2008 & 2009 & 2010 & 2006-2010 p. p. \\
\hline USA & 23.2 & 20.9 & 19.1 & 18.7 & 18.0 & -5.2 \\
\hline China & 5.5 & 5.8 & 6.0 & 7.5 & 8.4 & 2.9 \\
\hline Russia & 6.2 & 7.2 & 8.0 & 6.0 & 6.4 & 0.2 \\
\hline Japan & 3.9 & 3.5 & 3.2 & 3.3 & 3.2 & -0.7 \\
\hline India & 2.1 & 2.4 & 2.4 & 2.5 & 2.6 & 0.5 \\
\hline Brazil & 1.5 & 1.7 & 2.0 & 2.0 & 2.3 & 0.8 \\
\hline
\end{tabular}

Source: Own table based on data from Eurostat (2012). 


\section{Conclusion}

On the basis of changes in the global economy that were brought about by the process of globalisation and trade integration in the 1990s, the European Union often has to resist big pressures of competition in the world markets. In 2010, the European Union still took the first position among the leading exporters and importers in the world. The value of merchandise exports and imports of the Union individually achieved EUR 1.3 trillion and EUR 1.5 trillion. In order to secure the leading position in world trade, the European Commission presented internal and external agendas on which the European Union was focused in the period 2006 - 2010. The main idea consisted in the opinion that in a global economy, strong economies are competitive economies. And competitive economies are built on trade. Trade policy was considered as the main instrument for ensuring open markets and increasing trade opportunities for the EU companies.

The EU's trade strategy got the official name "Global - Europe: Competing in the World". The main priorities areas contained eight areas, namely: the WTO Doha Development Agenda, the launch of new competitiveness-driven free trade agreements, Transatlantic trade and competitiveness, China, the intellectual property rights enforcement, the renewed Market Access Strategy, public procurement and review of the Trade Defence Instruments. It means that Global Europe focused on the strengthening of the EU's trade upon multilateral and bilateral negotiations about trade liberalisation, and also covered other measures needed for ensuring fair trade. But my own analyses of the EU's market share showed that the tendency from the previous years continued. It means that the European Union suffered a decline of its share on the world merchandise exports and imports alike. The row of trade negotiations about launching new free trade agreements were not concluded and multilateral negotiations in the WTO also failed during the period 2006 - 2010. But the question that remains is if more favourable market access through free trade agreement is conclusive for the realisation of trade. The case of the EU - USA bilateral trade demonstrates that although the countries have not signed any preferential agreement, their trade relations are the biggest.

Analyses of the EU trade integration confirmed that the European Union was more open in 2010 than it was in 2006, especially on the import side. It results in a negative trade balance that the European Union recorded in the long term. The largest trade deficits were recorded in 2008 in the value of more than EUR 256 billion. Although Global Europe expected trade to contribute to new jobs, the rate of unemployment grew and was influenced by the overall worsened situation in the EU as well as the world market.

The most positive result of trade analysis is that during the period of $2006-2010$, the European Union increased the share of emerging markets represented by BRIC on its total exports. Contrary to BRIC, the share of the EU declined on the markets of developed countries, such as the USA and Japan. It was a reverse development than had been recorded before Global Europe started to be carried out.

The ex-post assessment of the Global Europe strategy shows that the newly set out priorities of the EU trade strategy until 2020 are correct. The idea of trade liberalisation remains, and the main task is to gain better access to the largest and fastest growing economies in the world (USA, Japan, Brazil, India, Russia and China). The new trade 
strategy of the European Union also focused on foreign direct investment that was not covered by the Common Commercial Policy before the Lisbon Treaty came into force. The success of trade strategy will depend on many factors, but one of them is the ability to speak with one voice at the world forums.

\section{References}

AGGARWAL, V. K., FOGARTY, E. A. (2004). EU Trade Strategies. Between Regionalism and Globalism. Palgrave Macmillan: New York, p. 249.

ARCAS, R. L. (2008). The European Union and the BRIC Countries in Strategic Trade Policy Areas. In: Theory and Practice of EC External Trade Law and Policy. Retrieved January 18, 2012 from http://www.asil.org/files/ielconferencepapers/leal-arcas.pdf

CEP II. CHELEM (2009). World Economic Overview. Retrieved January 20, 2012 from http://www.cepii.fr/anglaisgraph/bdd/chelem.htm

CEP II-CIREM (2011). Economic Analysis in Support of Bilateral and Multilateral Trade Negotiations. Retrieved Janury 23, 2012 from http://trade.ec.europa.eu/doclib/docs/2011/november/tradoc_148381.09.11.pdf

CURRAN, L., ZIGNANO, S. (2009). The Evolution of EU and Its Member States'Competitiveness in International Trade. CEP II-CIREM, ATLASS consortium. Retrieved January $\quad 19, \quad 2012 \quad$ from http://trade.ec.europa.eu/doclib/docs/2009/march/tradoc_142475.pdf

BUNGENBERG, M. (2010). Going Global? The EU Common Commercial Policy after Lisbon. In: European Yearbook of International Economic Law. Volume 1, Part 1, pp. 123-151.

ELSIG, M. (2002). The EU's Common Commercial Policy. Asghate Publishing Limited: Hampshire, p. 196.

EUR - Lex (2010). Consolidated Version of the Treaty on European Union. Retrieved January 20, 2012 from http://eurlex.europa.eu/LexUriServ/LexUriServ.do?uri=OJ:C:2010:083:0047:0200:EN:PDF

EUROPA. EU (2012). Common commercial policy. Retrieved January 21, 2012 from http://europa.eu/legislation_summaries/institutional_affairs/treaties/amsterdam_treaty/a 20000_en.htm

EUROPEAN COMMISSION (2006a). Trade. The Global Europe strategy. Retrieved June 16, 2011 from http://trade.ec.europa.eu/doclib/docs/2006/october/tradoc_130376.pdf

EUROPEAN COMMISSION (2006b). Trade. Commisission staff working document.The Global Europe: Competing In the World. A Contribution to the EU's Growth and Jobs Strategy. Retrieved June 24, 2011 from http://trade.ec.europa.eu/doclib/docs/2006/october/tradoc_130370.pdf 
EUROPEAN COMMISSION (2006c). Trade. Communication from the Commission to the Council and the European Parliament. EU - China: Closer partners, growing responsibilities. $\quad$ Retrieved January 24, 2012 from http://trade.ec.europa.eu/doclib/docs/2006/october/tradoc_130875.pdf

EUROPEAN COMMISSION (2008). Trade. Global Europe. EU performance in the global economy. Retrieved January 19, 2012 from http://trade.ec.europa.eu/doclib/docs/2008/october/tradoc_141196.pdf

EUROPEAN COMMISSION (2010a). Trade. Report on Progress achieved on the Global Europe Strategy, 2006 - 2010. Commission staff working document accompanying the Commission's Communication on „Trade, Growth and World affairs“. $\quad$ Retrieved $\quad$ January $\quad 20, \quad 2012$ from http://trade.ec.europa.eu/doclib/docs/2010/november/tradoc_146941.pdf

EUROPEAN COMMISSION (2010b). Trade. Commission Staff Working Document. Trade as a Driver of Prosperity. Accompanying document to the European Parliament, the Council, the European Economic and Social Committee and the Committee of the Regions. Trade, Growth and World Affairs. Trade Policy as a core component of the EU's $2020 \quad$ strategy. Retrieved January 27, 2012 from http://trade.ec.europa.eu/doclib/docs/2010/november/tradoc_146940.pdf

EUROPEAN COMMISION. DG TRADE [online]. Retrieved from http://ec.europa.eu/trade/

EUROSKOP.CZ (2011). Věcně o EU [on-line]. Retrieved from http://www.euroskop.cz/

EUROSTAT (2010). External and intra-European Union trade. Data 2004-09. Retrieved July 12, 2011 from http://epp.eurostat.ec.europa.eu/cache/ITY_OFFPUB/KSCV-10-001/EN/KS-CV-10-001-EN.PDF

EUROSTAT (2011). External and intra-EU trade. A statistical yearbook - data 1958 2010. Retrieved January $20, \quad 2012$ from http://epp.eurostat.ec.europa.eu/cache/ITY_OFFPUB/KS-GI-11-001/EN/KS-GI-11001-EN-TOC.PDF

$\begin{array}{lll}\text { EUROSTAT } & \text { [online]. } & \text { Retrieved }\end{array}$ http://epp.eurostat.ec.europa.eu/portal/page/portal/eurostat/home

GOODE, W. (2003). Dictionary of Trade Policy Terms. Fourth edition. Cambridge: Cambridge University Press, pp. 69, pp. 356.

KERR, A., GAISFORD, J. D. (2007). Handbook on International Trade Policy. Edward Elgar Publishing Limited: Cheltenham, p. 543.

KÖBELE, F. (2007). Global Europe Going Bilateral. The Political Economy of the EU's New Trade Policy Strategy. London School of Economics and Political Science.

MANDELSON, P. (2008). Globalisation needs a global „New Deal“. Retrieved January 20, $2012 \quad$ from http://trade.ec.europa.eu/doclib/docs/2008/june/tradoc_139102.pdf 
MANDELSON. P. (2007). Mandelson makes the case for a renewed EU in the European Union in the Global Age. Retrieved January 19, 2012 from http://trade.ec.europa.eu/doclib/docs/2007/march/tradoc_133799.pdf

MAHNKOPF, B. (2008). EU Multi-Level Trade Policy: Neither Coherent nor Development-Friendly. Retrieved January 18, 2012 from http://www.global-labour university.org/fileadmin/GLU_Working_Papers/GLU_WP_No.2.pdf

MESSERLIN, P., WANG, J. (2008). Redesigning the European Union's trade policy strategy towards China. Retrieved January 18, 2012 from http://www.ecipe.org/publications/ecipe-working-papers/redesigning-the-europeanunion2019s-trade-policy-strategy-towards-china

ŠTĚRBOVÁ, L. (2010). Impacts of the Lisbon Treaty on the EU Trade Policy. Retrieved January 21, 2012 from http://www.gcasa.com/conferences/budapest/papers/Sterbova.pdf

WOOLCOCK, S. (2007). European Union policy towards Free Trade Agreements. Retrieved January 24, 2012 from http://www.ecipe.org/publications/ecipe-workingpapers/european-union-policy-towards-free-trade-agreements

WTO. OECD. UNCTAD (2009). Report on G20 Trade and Investment Measures. Retrieved January 25, 2012 from http://www.oecd.org/dataoecd/56/48/43689944.pdf

WTO (2010). Trade to expand by $9.5 \%$ in 2010 after a dismal 2009. Retrieved January 20, 2011 from http://www.wto.org/english/news_e/pres10_e/pr598_e.htm

WTO (2011a). Trade Policy Review: European Union. Retrieved January 23, 2012 from http://www.wto.org/english/tratop_e/tpr_e/s248_sum_e.pdf

WTO (2011b). World Trade 2010, Prospects for 2011. Retrieved June 9, 2011 from http://www.wto.org/english/news_e/pres11_e/pr628_e.htm 